\title{
YOUNG PEOPLE OF THE IMPORTANCE OF HEALTHY EATING AND INFORMING
}

\author{
Marelle Grünthal-Drell
}

Maarika Veigel

Tallinn University Pedagogical College, Estonia

\begin{abstract}
Lately, the variety of health -related research conducted in Estonia and elsewhere in the world, has been increased. The proportion of studies about right nutrition has increased especially, which shows that people are more aware and considered about the important link between diet and health.

The aim of the research was to find out how young people evaluate their eating habits, what is their expertise in this field and what are the wishes and suggestions from them in relation to the nutrition information. In quantitative research for data collections were used surveys. The sample consisted of 131 young peole, aged 7-26 years.

Young people eat mostly unhealthy. This is primarily due to bad habits, which is related to the fast-paced lifestyle. It can be said that the youth nutrition knowledge is good, but implementation in practice is poor.
\end{abstract}

Keywords: added ingredient, eating habits, nutrient, nutritional needs, youth.

\section{Introduction}

In a short period of time young people have changed a way of eating in a large scale. Today they use mostly industrially produced foods and fast foods, which are often associated with negative aspects. Meals for many young people contain ,fast sugars“ with saturated fats, low protein and vitamins and excess of salt. There is parallely growing number of young people with health problems and overweight.

Tackling major risk behaviours (unhealthy diet, sedentary lifestyle) can help prevent many chronic diseases, which affect people over a long periods and generally have a slow progress. Some of them (diabetes) represent leading causes of mortality. But to be effective, such efforts need to be based on targeted health promotion, prevention and early detection (Public health, 2014).

Most people are ordinary citizens of the society, without the specific training of nutrition. Diet-related problems began to receive the attention of society from the 1950s. People ate mostly natural and near-natural state of foods in the past. Now, almost $3 / 4$ of our daily food on our dining room table is processed (Marks et al., 2005, Worobey et al., 2006). In The White Paper, "Europion Strategy of Nutrition, Overweight and Obesity related health issues „, for the European Parliament adopted a resolution (2008) of all the governments and parliaments of the world health organization states have mentioned that the diet-related diseases are taking the epidemic forms and belonging in to the 
reasons of major source of morbidity and mortality in Europe. There is the poor diet the major risk factor and the reason of death. Therefore a healthy diet should conform the individual's specific needs, based on the following criteria: nutritional, toxicological characteristics, digestibility of the food, the ecology of production.

Young people, 7-26 age, are forming 22.1\% from the population of Estonia at the beginning of year 2014. Young people aged 15-24 considered their health status as „good" in the year 2013. Thus, over the last decade, youth health ratings are improved (Batujeva, 2014).

Balanced diet is one of the mainstays of health, which is particularly important for the growing young organism. People are able to consume almost anything in modern society, so their consumption and consumer behavior study right now become very important. Dietary habits acquired in young age and follow during all life. There are influence from following factors: family, adults, culture, traditions. It is necessary to examine the eating habits of young consumers. We wish to emphasize young people's health and their rising awareness in terms of healthy nutrition.

It is important to have a healthy and balanced diet for young, active people. This means that the food has to be as diverse in culinary processing and fresh, also contain a sufficient amount of balance of the basic nutrients (Panchenko, 2005). Healthier foods are the ones you should eat every day, because they include substances for the growth of young organism, development and increase the resistance of the bodies vital. Less healthy foods are the ones you should eat less. These are especially processed foods, which contain the greater number of fat, sugar, salt, and various additives (Teesalu, 2006). A varied diet and high nutrient density is a prerequisite for obtaining of sufficient amount of minerals and vitamins from food (Deikina \& Jõeleht, 2009). Young daily energy consumption is relatively easily accommodated. It is more difficult to ensure proper nutritional balance of the food. Scientific and technological progress nowadays have added the definition „The theory of optimal or adequate diet”. This theory takes into account the changes that are taking place under the influence of food in the digestive system. The key here is the difference in the absorption of fission products also competition between them and forming products in digestive system, which are unnecessary and harmful to the body, the effects of the compounds. It should also be taken into consideration when making choices of food and drink also that the intermediates formed during digestion may either stimulate or inhibit the activity of the brain. All these issues must be considered on individual basics, to take into account the characteristics of the organism and gastrointestinal reactions (Simson \& Oja, 2010). Nutrition has a very different individual needs and changing lives. Organism's accessories like the amount of nutrients depends primarily on age, sex, physical and mental work proportions, also on the body's physiological state (Pappel \& Kuiv, 2001; Teesalu, 2006). 
From research of school pupils have conducted by Institute of Health Development of Estonia on 2006, appears that many teenage girls are trying to avoid eating. $42 \%$ of 15 -year-old girls had changed their eating habits during the last year to control their body weight. The majority of them had taken for diet. Study reveal that only half of the 15-year-old girls eat breakfast and hot lunch every day. Have mentioned fact that the majority of young people feel that eating in a public place is unpleasant, as well as eating in front of other coevals (Aasvee et al., 2009; Nilsson, 2011). Pomerantz et al. (2013) mention that there has developed a problem in the weight-lowering agents and tablets, which are available online, and uncontrolled use of these is as same dangerous as using drugs.

Research of Nutrition Habits And Satisfaction With School Food of School Pupils have conducted by Institute of Health Development of Estonia in 2012 mention that the most common foods in the morning at homes are mostly sandwiches, coffee / tea / juice, muesli / breakfast cereals, porridge and cheese curd for pupils. Foods, made from eggs eat rarely in the morning. Almost half of the pupils are eating vegetables salads and fresh fruit a few times a week, but not every day. Young people admit that the main reason to buy several snack from the school buffet (in all age) is that the stomach goes empty before the lunch break (Hillep et al., 2012). If people eat more sweets, then there you are slower and more passive with less control over ourselves (Simson\& Oja, 2010). Young women may have noticed a conscious diet (for example, ate more fruit). While people were quite aware of the fat content of food or alcohol as harmful, they usually were not willing to change their eating habits so easily. Food choice was decisive, however, the cost of food and smell. Young men cholesterol was quite high. Vitamins and minerals consumption were the main deficiencies of vitamins D, B2, iron, and calcium intake (Pomerleau et al., 2000).

Valery`s et al. (2012) study among young people in Australia, explained the strong connection between nutrition (diet), physical activity and obesity. Young people with overweight were less physically active. One third (1/3) of the subjects consumed at least twice a week fast food and deep fried food. Half of respondents ate fruit at least once a day and more than three-quarters (3/4) of the subjects vegetables.

Kornides et al. (2014) explained that cooking at home was positively associated with regular shared family meals, but the convenience and fast food consumption were negatively associated. In families, where at least one parent worked with part-time or was at home, were significantly more regular shared family meals than in families where both parents worked full-time. Also given attention to the importance of cooking skills and obstacles.

World nutritionists are in the opinion that the increase of food intolerance is caused by the fact that there are added the growing number of new food products into the human diet, the body has not enough time to get used with them. The immune system is ,programmed" to respond to everything what is 
foreign for the body (Simson \& Oja, 2010; Teesalu, 2006). And increasing share of corporate advertising campaigns targeted for younger customers. If the taste experience comes from an early age and from McDonald's and Hesburger, stay young people happy on the wide way of sweet, salty and greasy meals. Many young people will replace the fat diet with less fat content, products, advertising „light" products, so as to reduce feelings of guilt, which is caused by the eaten burgers and drunken lemonades. Fat is important taste carrier and it's replacement with protein or carbon hydrates will inevitably affect the taste. So should support the taste with new additives, but if the fat also will disappear beneficial vitamins (Nilsson, 2011).

An and Sturm (2012) did not find examining over 13 thousand Californian young people connections between diet providing environments existence (supermarkets, fast food places, shops nearby school or home) or consumption of food offered from there. It is noted that the major fast-food places, supermarkets etc. should encourage the consumption of a healthy diet, not induce overexploitation.

The European Union launched the reform of the fruit and vegetable sector in September 2007. The main purpose of that was to increase fruit and vegetable consumption. In approving the reform, was reported ,in view of the fact that obesity among school children has increased significantly, as soon as possible to submit the proposal for a school fruit program on the basis of its inherent benefits, practicability and administrative costs related to impact assessment" (Commission of the European Communities, 2008). Youth Work supports a healthy lifestyle and the health values and attitudes of young people with all it's activities. It requires workforce competencies and tools who work on the area of young people, consistent development of knowledge based approach to the target groups, training, tools and interventions to in paragraph (Youth Work Development Plan 2014-2020). There is Health Education, in among of other things, youth work's part and nutrition as part of it. From the position of health education, there is important that the desired behavioral changes become as habit and decision to change would be made by young adopted on the basis of values. There is unhealthy dietone of the types of risk behavior (Streimann et al, 2011).

The main organizations dealing with young people outside of school education in the compulsory education system are youth centers, information and counseling centers, hobby schools, youth organisations and groups. Youth centers are the main promoters of youth work (Youth Work Act, 2010). Youth info aim is to increase the range of options that are available to young people, providing to direct or indirect information from public life and enables young people to make independent choices in organizing their lives (Lange \& Rutjes, 2003). 


\section{The aim and research questions}

The aim of the research was to find out how young people evaluate their eating habits, what is their expertise in that field and what are their wishes and suggestions in relation to the nutrition information. The research questions were: how do young people evaluate their own eating habits? Who or what influences young people's eating habits? What do young people know about nutrition? Do young people have been informed enough about healthy diet? What are the recommendations from young people to youth-workers in order to raise awareness about nutrition among young people?

\section{Results}

The sample was selected on the principle purpose of the sample. The sample included young people aged 7-26 years, participated in a total of 131 young people from each age group: there were 4\% 7-11 years old young people. The most represented (43\%) were 17-21 age old young. The remaining $23 \%$ were in age 12-16 years and 30\% from 21-26 years old. The study took place in the spring of 2014.

Appeared that behavioural eating habits are as the main factors influencing food choice. $20 \%$ of respondents indicated that making food choices based on the food salubrity. We dare to believe, that there is more of a desire to act. The real situation and the desire of young people to eat healthily often do not coincide. This is also confirmed by the fact that the question of how to appreciate their own eating habits, only $5 \%$ of young people answered „very good". This, however, may in turn be due to the economic situation, as $16 \%$ of the respondents points out that these choices are particularly affected by the economic situation.

Respondents mentioned series of non-healthy foods (donuts, burgers, deep fried food, sweets, potato chips, other snacks) and there were asked to form the basis of their ranking. Most young people were limited by the list deep fried food $(38 \%)$. Then were more mentioned burgers, potato chips/snacks and donuts. The least restrictive by youth are sweets (37\%).

Most of the respondents (86\%) are aware of the fact that even if the diet is sufficient, it is possible that there is a deficiency of nutrients. By asking respondents to mention the diseases that are caused by incorrect diet and name a variety of nutrition-related diseases, most mentioned were: obesity, cardiovascular disorders, anorexia, bulimia, diabetes, allergy, aweak immune system, stress, depression, dental disorders, digestive problems, cancer, increased cholesterol, hyperactivity.

Generalizing the nutrition knowledge of young people, we can make the conclusion that knowledge is good, young people know which foods or what rations should be avoided and what prefer. In fact, young people are consuming foods that does not meet their needs quite often. Each option is worth 
considering, because each subsequent selection of new options, which in turn will affect all future choices. The habit has become an easy, but very difficult to change. Therefore, any forwarding, attention management, reporting and thus to contribute to young people's changing habits are necessary for young people. Early recognition, prevention is always better than dealing with the consequences later. The majority of respondents $(85 \%)$ believe that youth workers can raise the awareness of young people about healthy nutrition. Youthworker as an exemplar for young people came out from several proposals, which draws attention how much responsibility is in youthworker's work. It also shows how important is to have the wide horizons of youth workers, a large knowledge base, and complement themselves in the field of nutrition.

Most found mention the need to organize in the relevant subjects in schools, training courses, lectures, information sessions, as well as conducting a cooking theme in different keys. Respondents consider that cooking practices contributes to instilling healthy habits, and also to break the myth that healthy food does not taste good.

Appearedthat nutrition topics which have been covered by media and what are dealt in the school system, are known for young people. They are able to justify the myth of'light" products, know even about the intestinal rhythm work and the term ,processed food”. However, as reflected in the term „,cocktail effect" from the latest research and the reasons ,why white sugar is bad", has received little coverage in the media, and thus there are limited or lack of knowledge among young people in these issues. For example about white sugar, the white sugar increases the porosity of the intestinal wall and is the nutrient for pathological microflora, which also weakens the immune system, the body's homeostasis and promotes the violation of minerals out from the body (Simson \& Oja, 2010). The term ,cocktail effect” is a new and young people are not able to find link between foodadditives and reaction effects forthe body. However, the researchers who also examined that topic say that the first studies concerning the ,cocktail effect” will start to arrive (Nilsson, 2011).

From our research appeared that young people's assessment for themselves in general is: young people eat more unhealthy. By asking respondents to characterize the dietary habits with one word, main answeres of young people were; unhealthy, high-speed, unvaried, fast food, insufficient. $57 \%$ of respondents rated their eating habits passable or acceptable. Also from the reseach of the Institute ofHealth Development of Estonia 2006 conducted a health survey of school students reveals that only half of the 15-years-old eat daily breakfast and hot lunch (Aasvee et al., 2009; Nilsson, 2011). 


\section{Conclusion}

The research results obtained can be used in practice. Knowing that young people are interested in nutrition info, we should allow it for them. Human beings are not born with knowing how to make healthy choices in life: to eat a varied, balanced and according to individual needs. This is a skill that is acquired through the life and if are treated seriously and consciously, the more likely it is to live a fulfilling life. It is important to know that, mentioning the relevant data about health field for young people, we preventing health problems caused by unhealthy lifestyles, which in turn provides them fulfilling life.

Youth worker must be competent and able to share the nutritional knowledge to young people or direct them to that main point. By drawing attention to the dietary habits of young people, youth worker should explain the harmful effects of substances on the body, not only limited withstatements that one or the other food is bad for you. Youth worker`s work among young people carried out by the advice and information in the form of prevention, health education, must be with high quality, reasonable and understandable for young, which in turn ensures a high efficiency in the long run.

A person can consume almost everything in modern society,so the consumer and the consumer's behavior has become extremely important. People acquire eating habits in young age and maintain them throughout their life and there are influencing factors like the family, culture, traditions, it is also necessary to examine what are the eating habits of young consumers. Knowing that young people are interested in information of nutrition, should allow it to them.

Human beings are not born with knowledge how to make healthy choices in their life: to eat a varied, balanced and according to individual needs. This is a skill that is acquired through lifetime and if they are treated seriously and consciously, then more probable to live a full life. It is important to know that, reduceing health-relevant information for young people we canprevent the health problems caused by unhealthy lifestyles, which provides them valuable full of life. Today's young people rather eat unhealthily, it is primarily the result of bad eating habits in their opinion, as well as accelerating busy lifestyle. One of the key ofimprovement of the nutritionalsituation of young people is considered reformulation of foods. Till now, there is the most focused the reduction of salt, sugar, trans fats and saturated fatty acids to change the composition of processed foods.

The research results obtained can be used in practice. Youth workers must be competent to share general healthy nutritional knowledge to young people, or direct them to that point. By drawing attention to their dietary habits of young people, also would be able to explain the harmful effects of substances tothe organism and not to confined with the allegations that one or the other food is „bad for you“". 
Counselling and information, conducted by youth workers among the youth, asthe form of prevention and health education, must be quality and justified understandably for young, which in turn can ensure the long-term efficiency. The main recommendations for youth workers to raise young people's awareness of nutrition are: perform and use thematically training courses, information days, lectures, games, camps, study tours, workshops, posters, movies, campaigns. Promote healthy eating and the importance of personalized nutrition systematically, to help young people improve their eating habits and if necessary, redesign them.

As food production has become more and more industrial, only well-fed young people can pass their knowledge of food quality and influence, about food preparationfor future generations in later adulthood.

By making simple changes in daily food menu and the food menu refinement of the necessary nutrients, are obtained excellent results by nutritionists to improve the health problems of young people. Therefore, attention should be paid and to contribute to the future ofyoung people, a healthy diet assured of better health.

\section{References}

Aasvee, K., Streimann, K., Karelson, K., Oja, L., Trummal, A. (2009). Eesti kooliõpilaste tervisekäitumine 2005/2006: oppeaasta uuringu raport. Estonia.

An, R., Sturm, R. (2012). School and Residential Neighborhood Food Environment and Diet Among California Youth. American Journal of Preventative Medicine, 42 (2), 129-135.

Batujeva, V. (2014). Ülevaade muutustest noorte eluolus. Noorteseire aastaraamat 2013 noorsootöö tulemuslikkuse hindamine. SA Poliitikauuringute Keskus Praxis, ENTK.

Commission of the European Communities (2008). Euroopa Ühenduste Komisjon. Downloaded from http://eurlex.europa.eu/LexUriServ/LexUriServ.do?uri=SEC:2008: 2226:FIN:ET:PDF

Deikina, J., Jõeleht, A. (2009). Toitumis-ja toidusoovitused noortele. Downloaded from http://www2.tai.ee/Terviseinfo/Trykised/Toitumiss_noortele_vaatefail.pdf. Estonia.

Hillep, P., Pärnamets, E., Trubetskoi, E., Olev, H. (2012). Koolinoorte toitumisharjumused ja rahulolu koolitoiduga: Uuringu aruanne. Estonia Downloaded from https://intra.tai.ee/images/prints/documents/134564581422_Koolitoidu_uuring.pdf

Kornides, M.L.,. Nansel, T.R., Quick, V., Haynie, D.L., Lipsky, L.M., Laffel, L.M.B.,Mehta, S.N. (2014). Associations of family meal frequency with family meal habits and meal preparation characteristics among families of youth with type 1 diabetes. Vol. 40 (3), 405-411. John Wiley \& Sons Ltd, Child: care, health and development.

Lange, D., Rutjes, L. (2003). Noorte teavitamise ja nõustamise käsiraamat. CD-ROM. Arnhem: Sihtasutus Quia, ERYICA Downloaded from http://www.krink.ee/et/info-janostamiskeskus/dokumendid.html

Marks, D.F., Murray, M., Evans, B., Willing, C., Woodall, C., Sykes, C. M. (Eds.). (2005). Health Psychology Theory, Research and Practice: Second edition. London: SAGE Publications.

Nilsson, M-E. (2011). Toidudemagoogia. Tallinn.

Pantšenko, V. (2005). Tervise ABC tulevastele meistritele ja mitte ainult...: Sportliku ja terve elustiili käsiraamat. Tallinn.

Pappel, K., Kuiv, K. (2001). Toitumise alused. Tallinn. 
Pomeranz, J.L., Taylor, L.M., Austin, S.B. (2013). Over-the-Counter and Out-of-Control: Legal Strategies to Protect Youths From Abusing Products for Weight Control. American Journal of Public Health, Vol. 103 (2), 220-225.

Pomerleau, J., Mckee, M., Robertson, A., Vaask, S., Pudule, I., Grinberga, D., Kadziauskiene, K., Abaravicius, A. and Bartkeviciute R.(2000) Nutrition and lifestyles in the Baltic Republic, Vol. 32. London School of Hygiene and Tropical Medicine, PHP Departmental Publication.

Public health. Policy (2014) Downloaded from http://ec.europa.eu/health/major_chronic_ diseases/policy/index_en.htm

Simson, M., Oja, E. (2010). Toidu mõju lapse ajule, arengule ja käitumisele: Kuidas toitumisega leevendada ópiraskusi, hüperaktiivsust, autismi ja keskkonnamürkidega seonduvaid terviseprobleeme. Estonia.

Streimann, K., Hansen, S., Pertel, T. (2011) Tervis läbi noorsootöö. Räägime tervisest, juhendmaterjal noorsootöötajatele. Tervise Arengu Instituut. Tallinn.

Teesalu, S. (2006). Toitumine tõhusalt ja individuaalselt igas eas. Tartu.

Valery, P. C., Ibieble, T., Harris, M., Green, A. C., Cotterill, A.,Moloney, A., Sinha, A. K., Garvey, G. (2012). Diet, Physical Activity, and Obesity in School-Aged Indigenous Youths in Northern Australia. Journal of Obesity, 1-12.

White paper. (2008).Europion Strategy of Nutrition, Overweight and Obesity related health issues. Downloaded from http://eurlex.europa.eu/LexUriServ/LexUriServ.do? uri= COM:2008:0165:FIN:et:PDF

Worobey, J., Tepper, B.J., Kanarek, R. (Eds.). (2006). Nutrition and Behavior. A Multidisciplinary Approach. CABI Publishing.

Youth Work Development Plan 2014-2020 (2013). Noortevaldkonna arengukava 2014-2020. Downloaded from http://www.hm.ee/index.php?03240

Youth Work Act (2010) Noorsootöö seadus. Downloaded from https://www.riigiteataja.ee/ akt/13335738

Üldine aruanne Euroopa Liidu tegevuse kohta (2007). Downloaded fromhttp://europa.eu/ generalreport/pdf/rg2007_et.pdf 